\title{
A Protein Kinase from Colletotrichum trifolii Is Induced by Plant Cutin and Is Required for Appressorium Formation
}

\author{
M. B. Dickman, Y.-S. Ha, Z. Yang, B. Adams, and C. Huang \\ Department of Plant Pathology, University of Nebraska, Lincoln 68583-0722 U.S.A.
}

Submitted 4 October 2002. Accepted 6 January 2003.

\begin{abstract}
When certain phytopathogenic fungi contact plant surfaces, specialized infection structures (appressoria) are produced that facilitate penetration of the plant external barrier; the cuticle. Recognition of this hydrophobic host surface must be sensed by the fungus, initiating the appropriate signaling pathway or pathways for pathogenic development. Using polymerase chain reaction and primers designed from mammalian protein kinase $\mathrm{C}$ sequences (PKC), we have isolated, cloned, and characterized a protein kinase from Colletotrichum trifolii, causal agent of alfalfa anthracnose. Though sequence analysis indicated conserved sequences in mammalian PKC genes, we were unable to induce activity of the fungal protein using known activators of PKC. Instead, we show that the $C$. trifolii gene, designated LIPK (lipidinduced protein kinase) is induced specifically by purified plant cutin or long-chain fatty acids which are monomeric constituents of cutin. PKC inhibitors prevented appressorium formation and, to a lesser extent, spore germination. Overexpression of LIPK resulted in multiple, abnormally shaped appressoria. Gene replacement of lipk yielded strains which were unable to develop appressoria and were unable to infect intact host plant tissue. However, these mutants were able to colonize host tissue following artificial wounding, resulting in typical anthracnose lesions. Taken together, these data indicate a central role in triggering infection structure formation for this protein kinase, which is induced specifically by components of the plant cuticle. Thus, the fungus is able to sense and use host surface chemistry to induce a protein kinase-mediated pathway that is required for pathogenic development.
\end{abstract}

Additional keyword: morphogenesis.

A growing body of evidence indicates that signals released from both the plant and pathogen are crucial in determining the course of a parasitic relationship. Signal exchange following "recognition" events determines whether the interaction will be compatible or incompatible. It is not surprising that host molecules or surface architecture can be sensed by fungal pathogens, triggering specific developmental processes which promote disease development. The nature of such host signals, how the signals are perceived and propagated within the fungus, and how the process activates genes responsible for pathogenic development (including infection structure differentiation

Corresponding author: M. B. Dickman; Telephone: 402-472-2849; Fax: 402-472-2853; E-mail: mdickman@unlnotes.unl.edu

Current address of Z. Yang: Duke Medical Center, Durham, NC; current address of B. Adams: Department of Nematology, University of Florida, Gainesville; current address of C. Huang: Eli Lilly, Indianapolis, IN and host penetration) and subsequent colonization are beginning to be understood.

In response to host physical and chemical signals, fungi regulate the transcription of a number of genes, which trigger pathogenic development. Hoch and colleagues (1987) demonstrated that artificial ridges, which mimic those formed by the guard cells of leaf stomata, are necessary and sufficient to induce appressoria of Uromyces appendiculatus. Subtle alterations in ridge height prevented appressorium development and, thus, disease. This specific thigmotropic fungal response could involve the opening of mechanosensitive ion channels (Garrill et al. 1992) or disorganization of microtubules at the site of the germling's contact with the inductive ridge (Kim et al. 1991). Many pathogenic fungi can be induced to develop appressoria by germinating spores on hard surfaces. Although these nonstomatal penetrating fungal pathogens may not be as strict as $U$. appendiculatus in their structural requirements for appressorium formation, they still exhibit developmental specificity mediated by the nature of the surface nutrient availability and contact tropism (Tuker and Talbot 2001; Warwar and Dickman 1996). Though signals involved in growth orientation and in site recognition for some fungi are reasonably well advanced, the mode of signal reception and the biochemical pathways mediating these changes are poorly understood. A number of proteins and mRNAs accumulate during later stages of appressorium development but are unlikely to be involved in signal perception (Bhairi et al. 1989, 1990; Xuei et al. 1992).

Prior to establishment of infection, fungi must overcome the external barrier of the plant, the cuticle. Plant cuticles are the outermost barrier of aerial parts of all plants. Cutin, the primary structural polymer of the cuticle, comprises 50 to $90 \%$ of the cuticle. Cutin is composed mainly of esterified hydroxy and epoxy fatty acids which are 16 or 18 carbons in length. Numerous studies have examined the manner by which fungi traverse this barrier; enzymatic degradation, physical pressure, or both exerted by the appressorium are believed to play major roles in breaching the cuticle (Dickman et al. 1989; Dixon et al. 1999; Howard et al. 1991). Convincing evidence for such physical force has been presented for Magnaporthe grisea, causal agent of rice blast disease (de Jong et al. 1997). On the other hand, cutin fatty acids trigger transcriptional induction of a cutinolytic enzyme (cutinase) in Fusarium solani f. sp. pisi (Woloshuk and Kolattukudy 1986). This enzyme has been suggested to be important for chemical dissolution or softening of the cuticle in order to facilitate fungal penetration (Kolattukudy 1985). However, this scenario has not been confirmed in a number of cutinase gene-disruption experiments (van Kan et al. 1997); thus, inactivation of a cutinase gene does not always impair fungal penetration and subsequent host colonization and it is plausible that, at least in some cases, cutinase is important during saprophytic growth of fungi by facilitating catabolism of plant debris. 


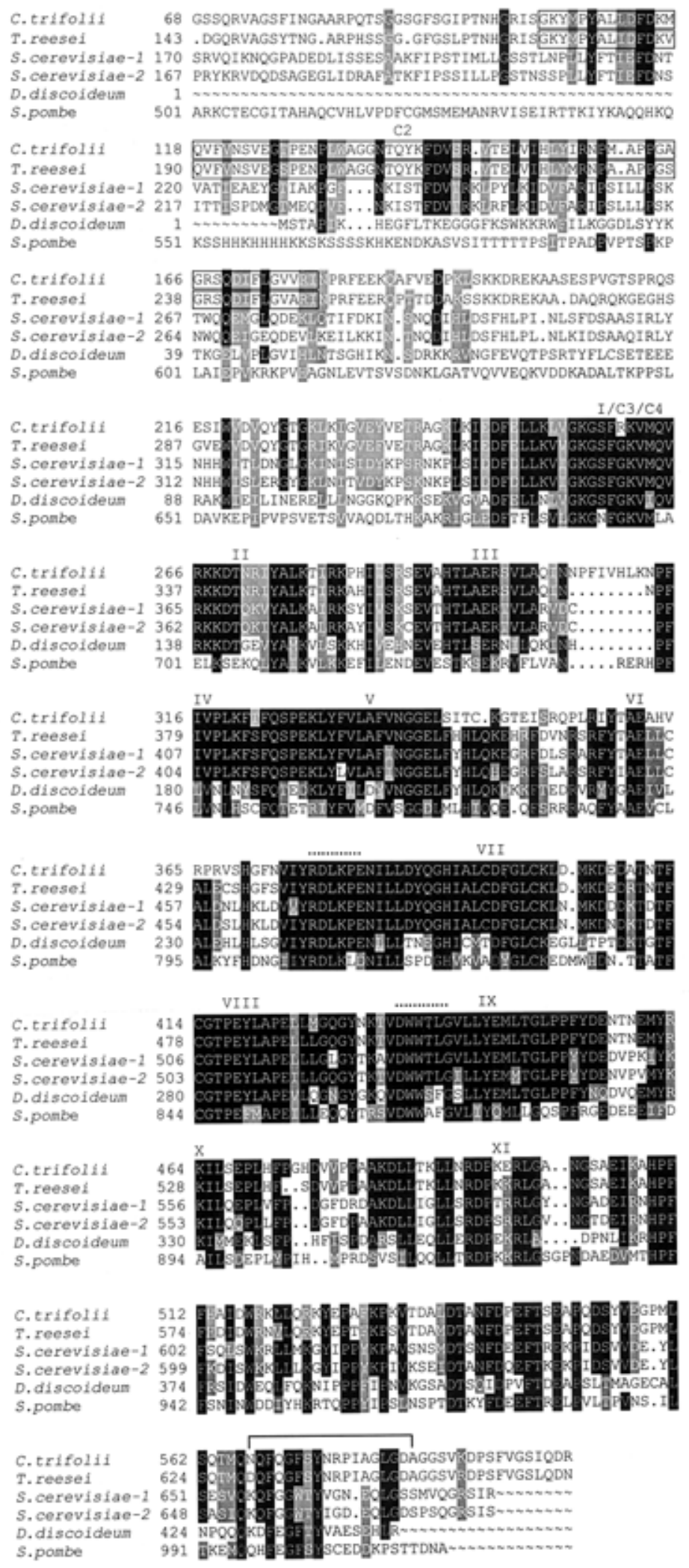

Fig. 1. Alignment of the amino acid sequences of lipid-induced protein kinase (LIPK) with other fungal protein kinase C sequences (PKCs). PTK1 (U05811) from Trichoderma reesei, YPK1 (M21307) from Saccharomyces cerevisiae-1, Rac- $\alpha$ (U15210) from Dictyostelium discoideum, and PKC2+ (D14338) from Schizosaccharomyces pombe were used for sequence alignment. YKR2 (M24929) is another related protein kinase C from Saccharomyces cerevisiae-2. The dotted lines indicate primer locations used for polymerase chain reaction and cDNA isolation. The bracketed area indicates the location in LIPK where reacted with the PKC $\varepsilon$ antibody peptide epitope. C2 homologous sequences are boxed. The 11 conserved kinase catalytic domains are shown in roman numerals. 
Colletotrichum trifolii is the causal agent of alfalfa anthracnose. When a spore of $C$. trifolii encounters an alfalfa leaf surface, the spore attaches and undergoes an orchestrated developmental sequence prior to attempted colonization. This process initiates with spore adherence to the host cuticle, continues with spore germination and germ tube formation, and culminates with differentiation into an infection structure: the appressorium. This highly melanized structure is required for successful penetration and subsequent colonization of intact host tissue (Dickman 2000a,b; Dickman et al. 1995). Mutants of $C$. trifolii and other fungal phytopathogens defective in appressorium formation or function are nonpathogenic (Warwar et al. 2000; Yang and Dickman 1997, 1999)

Prepenetration of fungal development occurs on the plant cuticle, a hydrophobic, lipid milieu; therefore, we suspected that lipid-induced signaling molecules such as protein kinases, in particular, might trigger these processes. We used polymerase chain reaction (PCR) and primers designed to amplify sequences conserved in the catalytic domain of the mammalian lipid-activated protein kinase C. Members of this family of phospholipid-dependent, serine- or threonine-specific kinases (collectively known as PKC) respond to extracellular signals by receptor-mediated hydrolysis of phosphatidylinositol bisphosphate to generate the second messengers, diacylglycerol (DAG) and inositol triphosphate $\left(\mathrm{IP}_{3}\right)$. DAG directly activates PKC. These kinases are key components in the phosphatidylinositol cascade which, in various animal cell types, evokes a wide variety of responses, including cell proliferation, regulation of gene expression, membrane transport, and cytoskeletal organization (Azzi et al. 1992). In addition, PKC is involved with a number of mammalian diseases (Grant and Jarvis 1996; Jarvis et al. 1996), is a protooncogene (Rahmsdorf and Herrlich 1990), and can drive cells to apoptosis (Grant and Jarvis 1996). In this article, we describe cloning and characterization of a $C$. trifolii serine or threonine lipid-induced protein kinase (LIPK). Chemical inhibition of LIPK with certain PKC inhibitors inhibited appressorial differentiation and, to a lesser extent, conidial germination. Interestingly, this gene is transcribed rapidly by plant cutin as well as cutin monomeric fatty acids, but not structurally related synthetic analogs. Overexpression of LIPK leads to aberrant abundant appressorium formation. Targeted insertional inactivation of this gene completely prevents appressorial formation, reduces spore germination, and inhibits pathogenicity.

\section{RESULTS}

\section{Cloning and characterization of LIPK.}

The association of the PKC family with lipid activation as well as its role in mammalian development and disease-related phenomena prompted a search for a functional homolog in $C$. trifolii. PCR primers were designed based on the highly conserved C1 domain (Nishizuka 1988), which is a hallmark of all PKCs, and domain VIII in the catalytic domain, which is a general motif for both cAMP-dependent protein kinase (PKA) or PKC (Hanks and Quinn 1991). By manipulating primer length and levels of degeneracy, we obtained a unique 400-bp fragment, which was used to screen a $C$. trifolii cDNA library generated from germinating conidia.

In all, $5 \times 10^{3}$ independent recombinant phages were screened and 13 strongly hybridizing plaques were isolated. Phage DNA purified from individual clones was digested with EcoRI, which separated the insert from the phage arms. Agarose gel electrophoresis and Southern hybridization using the PCR-generated probe yielded three individual clones, the longest of which had a 2.4-kb insert and which was further characterized. This cDNA insert was subcloned in pBluscript $\mathrm{KS}^{+}$and both strands were completely sequenced. The deduced amino acid sequence for this gene, which was designated LIPK, is shown in Figure 1.

The deduced polypeptide has a predicted length of 600 amino acids (aa) with a molecular weight of $72 \mathrm{kDa}$ and contains all 11 conserved kinase catalytic domain regions (Hanks and Quinn 1991). Using TFASTA and GAP programs, LIPK shares $78.9 \%$ identity and $81.5 \%$ similarity with PTK1 in Trichoderma reesei (Morawetz et al. 1994), 45.1\% identity and $51.6 \%$ similarity with Saccharomyces cerevisiae YKR2 (Kubo et al. 1989), and $43.8 \%$ identity and $51.7 \%$ similarity with $S$. cerevisiae YPK1 (Maurer 1988). Both YPK1 and YKR2 are putative PKCs in budding yeast (Fig. 1). LIPK also has $33 \%$ identity and $43 \%$ similarity with the PKC1 protein of Blumeria graminis (Zhang et al. 2001). The N-terminus of LIPK appears to be distinct, resembling only the N-terminus of PTK1, indicating that LIPK and PTK1 may be homologous. LIPK also contains homologous sequences to the $\mathrm{C} 2$ and $\mathrm{C} 4$ regions of PKCs (Hanks and Quinn 1991) but lacks the phorbol ester-binding $\mathrm{C} 1$ region as well as the calcium-binding region in $\mathrm{C} 2$ which are conserved among the conventional and novel PKCs from higher eukaryotes (Morawetz et al. 1996), but whether this is of functional significance is unclear. Amino acid sequence alignment of LIPK and sequences of genes with highest levels of homology using TFASTA and BLAST database searches are shown in Figure 1.

The amino acid sequence in the catalytic region of LIPK has a high degree of identity with mammalian PKC genes (e.g., $42 \%$ with human $\mathrm{PKC} \varepsilon$ ). However, using in vitro expression assays, calcium and phorbol esters did not activate LIPK from C. trifolii (data not shown). We also have been unable to induce enzyme activity of this protein when synthesized in Escherichia coli or in total fungal protein extracts, using known PKC activators such as diacylglycerol and phorbol esters. Sequence analysis is consistent with this observation, because neither phorbol ester nor calcium-binding domains are present. Based on these data, we are reluctant to definitively classify this gene as an authentic PKC. Moreover, there are reports of lipid-induced protein kinases which are structurally distinct from known PKCs, particularly in the regulatory domain, known as protein kinase $\mathrm{N}$-type protein kinases (Mukai et al. 1996). Phylogenetic analysis support these observations (see below); thus, we have designated this gene lipk (lipid-induced protein kinase).

From Southern analysis under high and low stringencies, lipk is a single copy gene in $C$. trifolii. lipk expression in different cell types was examined by Northern blot analysis using total cellular RNAs extracted from mycelia, spores, germinating spores, and appressoria (Fig. 2). mRNA from $C$. trifolii showed a single band of $2.4 \mathrm{~kb}$ which was strongly expressed during conidial germination and appressoria development (Fig. 2, lane A) with lower expression in mycelia

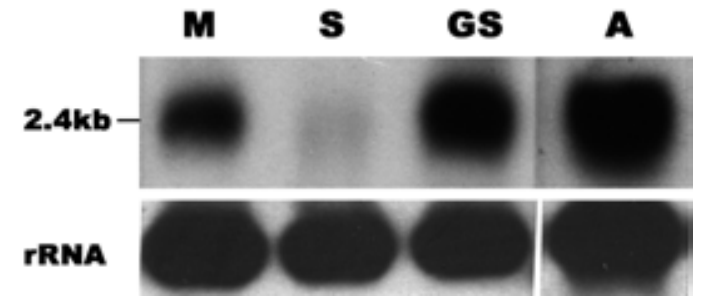

Fig. 2. RNA blot of lipid-induced protein kinase gene (lipk) expression during fungal development. Approximately $10 \mu \mathrm{g}$ of total RNA for each sample was loaded. Total RNA was isolated from actively growing mycelia (M), spores (S), germinating spores (GS), and appressoria (A). 
and spores. We expressed LIPK as a fusion protein in E. coli, and performed Western blots with a panel of PKC antibodies. Only the PKCE antibody strongly cross-reacted with LIPK. The PKC $\varepsilon$ antibody also reacted with LIPK in total fungal protein extracts (Fig. 3A). LIPK also is able to autophosphorylate, indicating that it is a functional kinase (Fig. 3B). Moreover, the developmental expression pattern of PKCE antibody reactive protein resembled the expression pattern of the 2.4-kb Northern reactive mRNA. Sequence alignment of LIPK with the peptide from which the PKC• $\varepsilon$ antibody was generated showed $50 \%$ identity and $83 \%$ similarity with LIPK. This region in LIPK however was at the carboxy terminus of LIPK (Fig. 1, presumable catalytic domain); however, in the mammalian $\mathrm{PKC} \varepsilon$, it was in the amino terminal region (regulatory domain). The functional significance of this observation, if any, is unclear.

\section{Phylogenetic analysis.}

An unrooted gene genealogy of LIPK is presented in Figure 4. The lipk gene is most closely related to the protein kinaseencoding gene, pkt1, from $T$. reesei, and does not form a clade with other PKC genes. Genealogical relationships among genes within their respective classes are discordant with commonly accepted hypotheses of eukaryotic phylogeny, suggesting ancient gene duplication events followed by lineage sorting (Goodman et al. 1982). The present analysis suggests that, overall, the different classes appear to be monophyletic. For example, the PKC and protein kinase B (PKB) families form mutually exclusive clades. An exception to this is the presence of a yeast $p k a$ in a clade of serine or threonine kinases and lipk genes. However, relationships among the gene classes, as well as within the PKC family, do not reflect predicted and well-corroborated organismal phylogenies. The sampled genes within the PKC family appear to be paralogous, yet functionally conserved, whereas $p k a, p k b, p k c$, and lipk genes apparently evolved novel functions following duplication of an ancestral gene.

\section{Inhibitor studies.}

To examine LIPK function in $C$. trifolii, four PKC inhibitors were tested for their effect on $C$. trifolii growth and development. No effects were observed following treatment with bisindolymaleimide (Martiny-Baron et al. 1993) and rottlerin (Gschwendt et al. 1994) at concentrations as high as

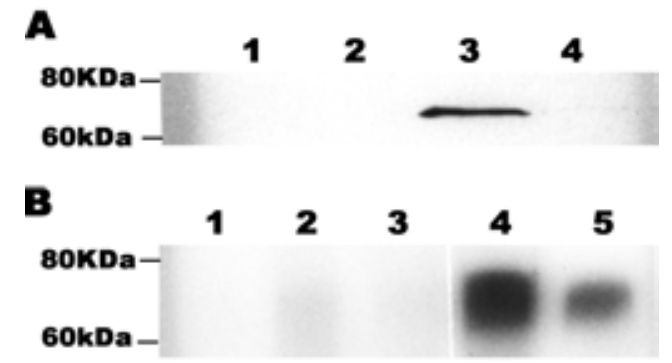

Fig. 3. Protein kinase $\mathrm{C}$ sequence $(\mathrm{PKC}) \varepsilon$ antibody can immunoprecipitate lipid-induced protein kinase (LIPK); A, $50 \mu \mathrm{g}$ of total fungal protein isolated from germinating spores of Colletotrichum trifolii was immunoprecipitated with PKC antibodies, run on a sodium dodecyl sulfate-polyacrylamide gel electrophoresis (SDS-PAGE) gel, and autoradiographed. Lane 1, control, proteins treated with rabbit immunoglobulin G; lane 2, PKC $\alpha$ antibody; lane 3, PKC $\varepsilon$ antibody; lane 4, PKC $\beta$ antibody. B, LIPK can autophosphorylate. LIPK expressed in Escherichia coli was extracted and a protein kinase activity assay (Gibco) containing $\left[\mathrm{P}^{32}\right]$-ATP was used as described. Proteins were immunoprecipitated with PKC antibodies and run on an SDS-PAGE gel. Lane 1, no antibody; lane 2, PKC $\alpha$ antibody; lane 3, no radiolabel; lane 4, PKCe antibody (10×); and lane 5, $\mathrm{PKC} \varepsilon$ antibody $(1 \times)$.
$50 \mu \mathrm{M}$ (data not shown). Ro31-8220 affected both conidial germination and appressorial development at high concentrations $(50 \mu \mathrm{M})$ but was the most potent inhibitor of appressorial development (Table 1). Ro31-8220 nearly abolished all appressorial development at $10 \mu \mathrm{M}$. Staurosporine, however, was the most potent inhibitor in $C$. trifolii morphogenesis, but this may be attributed to its broad range of nonspecific inhibition of serine or threonine protein kinase activity. As little as $100 \mathrm{nM}$ of staurosporine affected both conidial germination and appressorial development; at 1 $\mu \mathrm{M}$, staurosporine inhibited approximately $90 \%$ germination, and also inhibited appressorial development by $95 \%$ (Table 2). These results are consistent with the involvement of LIPK in C. trifolii in the initiation of appressorial differentiation.

\section{Cutin and cutin monomers induce lipk.}

Based on enzyme assays, sequence analysis, and phylogenetic studies, LIPK is not likely in the PKC family of kinases. In a previous study in our lab designed to identify environmental parameters that stimulate $C$. trifolii morphogenesis, we noted that plant cutin appeared to stimulate LIPK expression in ungerminated conidia (Buhr and Dickman 1997). Therefore, we investigated effects of cutin and its components on expression of lipk. Purified cutin rapidly (15 min) induced lipk expression as measured by Northern blots using RNA from $C$. trifolii spores suspended in water. We then incubated $C$. trifolii conidia in the presence of known monomeric constituents of cutin, including 9, 12-octadecanoic (linoleic) acid; 9, 10, 16-trihydroxyhexadecanoic (aleuritic) acid, 8, 16-dihydroxyhexadecanoic acid, and the noncutin component, 16-hydroxyhexadecanoic acid. Of these long-chain fatty acids, only those present in plant cutin and. Therefore. only those present on plant surfaces induced lipk expression (Fig. 5).

\section{LIPK is required for normal appressorium development and pathogenicity in $C$. trifolii.}

To more precisely evaluate the function of LIPK, we specifically altered lipk expression in two ways: i) by overexpression using a strong constitutive promoter and ii) by DNA-mediated gene replacement. We used the Aspergillus nidulans glyceraldehyde phosphate dehydrogenase promoter (Punt et al. 1990) to overexpress lipk. Under conditions which readily induce appressoria in $C$. trifolii (glass slides inoculated with water spore suspensions), multiple, aberrant appressoria were produced (Fig. 6B). These transformants conidiated, grew similarly to wild type, and were morphologically indistinguishable from the wild type, except for appressorium development. In addition, these overexpressing strains were able to form appressoria in rich (yeast extract, peptone, soluble starch [YPSS]) media, which does not occur in wild-type isolates.

In gene replacement experiments, from 57 hygromycinresistant colonies, two mutants were identified harboring a lipk disruption as determined by PCR. The gene disruption was validated by Southern blot analysis (Fig. 7A). Northern analysis of these transformants confirmed that lipk expression was inhibited (Fig. 7C, lanes 2 and 3). On solid media, lipk disruptants were indistinguishable from wild-type $C$. trifolii in terms of growth rate. These mutants, however, were impaired in spore germination (90\% wild type versus $23 \%$ disruptants), suggesting that lipk expression is at least partially required for this process. In addition, none of the germinating spores from the disruptants were able to develop appressoria on hard surfaces (Fig. 6D).

Importantly, pathogenicity tests showed that LIPK expression is required for disease development on intact alfalfa 
tissue (Fig. 8). Using equivalent numbers of spores from wildtype and disruptant strains, with detached leaf assays, no appressoria were observed in the transformants and, although germ tubes and hyphae could be seen microscopically (data not shown), disease did not occur. In contrast, the wild-type $C$. trifolii formed appressoria, penetrated leaf tissue, and caused typical anthracnose lesions (Fig. 8 A versus B). The $C$. trifolii disruptants, however, were able to cause disease on alfalfa leaves that were wounded prior to inoculation (Fig. 8D). Moreover, conidia recovered from these lesions remained hygromycin B-resistant, and PCR analysis confirmed the replacement genotype. Similar results were obtained when whole plants were used (data not shown). Taken together, these results indicate that LIPK is required for appressorium development and pathogenicity on intact plant tissue.

\section{DISCUSSION}

In this article, we describe the cloning and functional characterization of a lipid-induced protein kinase from $C$. trifolii. The lipk gene was identified in a screen designed to isolate $C$. trifolii PKC-like genes. PKC genes have been isolated from S. cerevisiae (Oliver et al. 1992), A. niger (Morawetz et al. 1996) B. graminis (Zhang et al. 2001), and $T$. reesei (Morawetz et al. 1994, 1996). Both B. graminis and T. reesei harbor $\mathrm{PKC}$-like genes that are activated by traditional
PKC activators, DAG, or phorbol esters, whereas the others do not. In many cases, classification and function were deduced from primary sequence alignments (e.g., BLAST). Indeed, when LIPK sequence was compared by BLAST and TFASTA, PKC proteins were most similar to LIPK and it could be erroneously inferred that LIPK belonged to the PKC family. In addition to the catalytic domain similarity, LIPK shares homology in the pseudosubstrate region (House and Kemp 1987), which is also diagnostic for PKC; however, whether this is of functional significance is unclear (not shown). However, we were unable to induce LIPK activity by DAG or phorbol esters and phylogenetic analysis of lipk sequences revealed that LIPK is as close to PKA or PKB as it is PKC. A recent case that clearly shows the limitations of using rankings of BLAST scores as a surrogate for phylogenetic analyses is the reanalysis of claims of bacterial genes horizontally transferred to the human genome (Stanhope et al. 2001). Methods based explicitly on evolutionary or biological principles can be expected to give more accurate and reliable results than BLAST scores (Eisen 1998).

LIPK directly affects appressorium formation because gene knockouts were completely defective in appressorium development and lipk overexpression induced abnormal, multiple appressoria. Generally, $C$. trifolii forms one appressorium/conidia. Transformants constitutively expressing LIPK produced multiple appressoria, which were misshapen

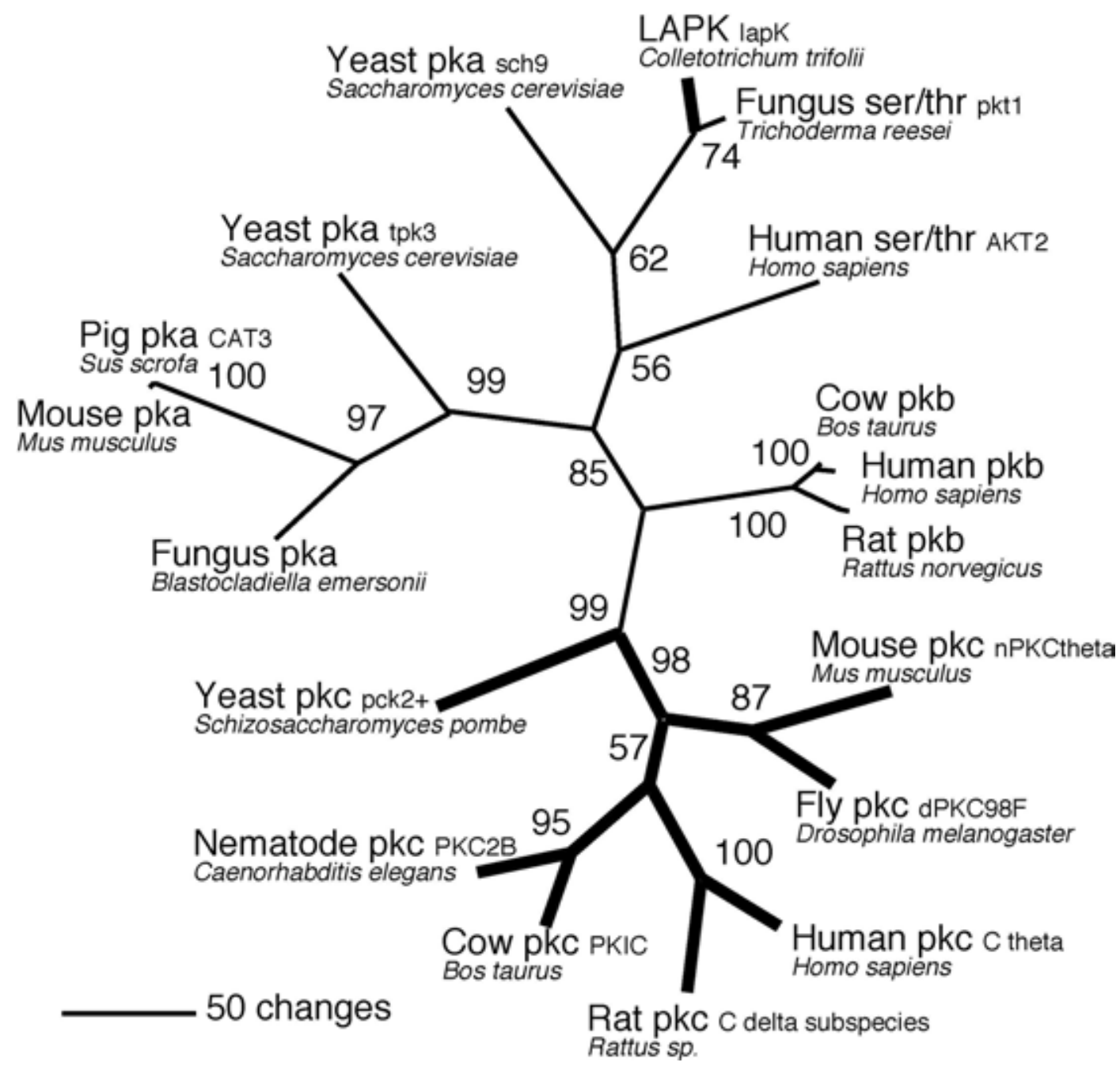

Fig. 4. Gene genealogies among four classes of protein kinase-encoding genes. Branch support indices appear at each node (percentage of bipartitions found in one or more trees, 100,000 quartets puzzling steps). Thick branches denotes lipid-induced protein kinase (LIPK) and members of the protein kinase $\mathrm{C}$ sequence $(\mathrm{PKC})$ gene class. 
and, in some cases, stacked on top of each other, a phenotype that has never been seen previously.

Unlike many appressorium-related genes whose expression is contact dependent, LIPK expression is contact independent because transcription of lipk is induced rapidly in liquid still culture containing cutin as the sole carbon source (Buhr and Dickman 1997). There are a number of examples where it has been shown or suggested that appressorium initiation is contact dependent, including $C$. trifolii and $M$. grisea (Dickman et al. 1995; Tuker and Talbot 2001). Thus, lipk represents a gene necessary for appressorium formation but does not require surface contact for induction, though LIPK expression does depend on host surface chemistry. However, we were unable to induce appressoria in liquid shake culture containing cutin, suggesting that additional factors are required. Such factors are either contact dependent or expression is inhibited in shake cultures. In addition to bypassing the requirement for surface contact to induce differentiation, the overexpressing LIPK transformants also formed appressoria under conditions of rich nutrition. C. trifolii normally only forms appressoria on hard surfaces under conditions of relative starvation, and never develop appressoria when growing in rich nutritional media. The increased expression of the lipk gene apparently is sufficient to bypass both the physical and chemical signals normally required for infection structure development.

A variety of PKC inhibitors, primarily used in mammalian systems, were screened for their ability to effect $C$. trifolii prepenetration development. Most of the compounds tested (e.g., bisindolymaleimide, rottlerin, and chelerythrine chloride) had no discernable morphological affects on the fungus. This is not all together surprising because these inhibitors are relatively specific for $\mathrm{PKC}$, inhibition is based on interaction with the regulatory region of PKC, and LIPK is not a typically regulated PKC. Staurosporine potently inhibited both conidial germination and appressorium formation in C. trifolii (Table 1), but staurosporine, though considered to be the most potent PKC inhibitor (Tamaoki et al. 1986) is a general serine or threonine kinase inhibitor; thus, such effects may be attributable to nonspecific activities. However, both Ro318220 and Go6976 (Martiny-Baron et al. 1993) effectively blocked appressorium development and, to a lesser degree, germination. However, though these inhibitors are considered highly selective for PKC, the possibility of alternate targets cannot be entirely discounted; for example, Ro31-8220 can also inhibit protein kinase A, although not as strongly as PKC.

In addition to the inhibition of appressorium formation, the most significant phenotype in the lipk replacement strains was the inability to cause disease on intact host tissue. Conidia from disruptants inoculated onto either detached leaves or entire plants germinated (albeit at a reduced frequency), but were unable to grow, reproduce, and elaborate any symptoms.

Table 1. Effect of Ro31-8220 on Colletotrichum trifolii conidial germination and appressorial development

\begin{tabular}{|c|c|c|}
\hline \multicolumn{2}{|c|}{$\overline{\operatorname{Ro31-8220}(\mu \mathrm{M})^{\mathrm{a}}} \overline{\text { Germination }(\%)^{\mathrm{b}}}$} & \multirow{2}{*}{$\begin{array}{c}\text { Appressorial development }(\boldsymbol{\%})^{\mathrm{c}} \\
>90\end{array}$} \\
\hline 0 & $>90$ & \\
\hline 10 & $78.5 \pm 12.2$ & $3.7 \pm 3.1$ \\
\hline 25 & $36.0 \pm 9.3$ & $0.3 \pm 0.6$ \\
\hline 50 & $7.5 \pm 3.0$ & 0 \\
\hline 100 & $2.0 \pm 1.0$ & ND \\
\hline
\end{tabular}

${ }^{a}$ Spores were resuspended in distilled water and placed on glass slides.

${ }^{\mathrm{b}}$ Germination rate was determined from direct microscopic examination of at least 300 conidia per each concentration of R031-8220. All experiments were performed in triplicate.

${ }^{c}$ Appressorial development was determined using $10^{3}$ of germinated spores at each concentration of Ro31-8220. ND = not determined.
However, characteristic lesions and acervuli (indicative of reproduction) were observed when leaves were wounded prior to inoculation with either wild-type or knock-out strains. The fact that these lipk-deficient strains could colonize wounded leaves and produce acervuli as well as lesions indicates that the loss of pathogenicity in these knock-out isolates was not due to specific defects in virulence, but rather to a failure in pathogenic development, namely appressoria.

Protein phosphorylation or dephosporylation is clearly the standard currency by which eukaryotic cells respond to both extrinsic and intrinsic signals. Filamentous fungi are no exception to this theme. Recent reports illustrate the fundamental importance of this reversible post-translation modification in nearly every facet of fungal biology, including pathogenic development (Dickman and Yarden 1999). For example, PKA genes from several fungi have been shown to affect growth, morphogenesis, and virulence. And recently, a potential substrate for the Ustilago maydis PKA has been reported (Durrenberger et al. 2001). In $C$. trifolii, targeted inactivation of the PKA catalytic subunit prevents infection of intact alfalfa tissue, because the fungus cannot penetrate the cuticle, despite apparently normal appressorium development (Yang and Dickman 1997). This observation is somewhat similar to that reported in $M$. grisea, the rice blast fungus, where expression of catalytic subunit of PKA is necessary for penetration (Xu et al. 1997). Further work with $M$. grisea indicated that glycerol accumulates to extremely high concentrations in the appressorium, which is believed to facilitate mechanical breaching of the host cuticle. PKA disruptions in $M$. grisea result in reduced glycerol accumulation in the appressorium, presumably accounting for the penetration defect (Thines et al. 2000). Inactivation of the regulatory subunit gene of the $U$. maydis resulted in strains able to colonize host tissue (maize) normally, but which failed to produce galls (Gold et al. 1997). Thus, PKA is required for normal growth and development in a number of phytopathogenic fungi.

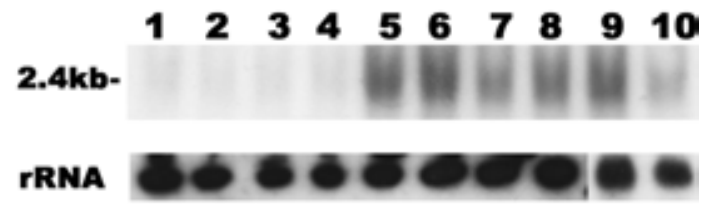

Fig. 5. Induction of lipid-induced protein kinase gene (lipk) transcription by various fatty acids. Total RNA was extracted from Colletotrichum trifolii spores that were treated with water (lanes 1 and 2); 16hydroxyhexadecanoic acid (lanes 3,4); 9,12-octadecaneoic acid (linoleic acid) (lanes 5,6); 9,10,16-trihydroxyhexadecanoic acid (aleuritic acid) (lanes 7,8); and 8,16-dihydroxyhexadecanoic acid (lane 9,10). Lanes 1, $3,5,7$, and 9 were induced for $15 \mathrm{~min}$. Lanes 2, 4, 6, 8, and 10 were induced for $30 \mathrm{~min}$.

Table 2. Effect of staurosporine on Colletotrichum trifolii conidial germination and appressorial development

\begin{tabular}{lcc}
\hline Staurosporine $(\boldsymbol{\mu M})^{\mathbf{a}}$ & Germination $(\boldsymbol{\%})^{\mathbf{b}}$ & $\begin{array}{c}\text { Appressorial } \\
\text { development }(\boldsymbol{\%})^{\mathbf{c}}\end{array}$ \\
\hline 0 & $83.3 \pm 4.8$ & $>90$ \\
0.1 & $65.2 \pm 10.7$ & $26.5 \pm 3.4$ \\
0.5 & $34.9 \pm 5.4$ & $15.5 \pm 3.0$ \\
1 & $13.8 \pm 4.4$ & $3.3 \pm 1.5$ \\
5 & ND & 0 \\
\hline
\end{tabular}

${ }^{a}$ Spores were resuspended in distilled water and placed on glass slides.

${ }^{\mathrm{b}}$ Germination rate was determined from direct microscopic examination of at least 300 conidia per each concentration of staurosporine. All experiments were performed in triplicate. ND $=$ not determined.

${ }^{c}$ Appressorial development was determined by using $10^{3}$ of germinated spores at each concentration of staurosporine. 
Mitogen-activated protein kinases also have been isolated from filamentous fungi. Gene disruptions affect pathogenic or development-altered phenotypes. A particularly notable example is work by Xu and Hamer, who have identified MAP kinase genes in $M$. grisea via degenerate PCR screens (Xu and Hamer 1996). PMK1 complements yeast FUS3/KSS1 double mutants with which it shares significant sequence similarity. More importantly, insertional inactivation of PMK1 blocked pathogenicity. Transformants did not form appressoria, explaining, in part, the nonpathogenic phenotype; however, wounding failed to overcome the block in pathogenicity, indicating that the PMK1 knockout resulted in pleiotropic effects. PMK1 deletion mutants were indistinguishable from the wild type during in vitro vegetative growth. Thus, these MAPK mutants could not respond thigmotropically for appressorium development and could not infect or colonize host tissue during pathogenic growth in the plant. A second MAPK, MPS1, also was isolated and mps 1 mutants had defects in cell wall integrity similar to yeast slt 2 mutants, to which this gene also is most similar in sequence $(\mathrm{Xu}$ et al. 1998). MPS1 mutants had a number of phenotypes, including female sterility, reduced conidiation, and a failure to penetrate. It is apparent that filamentous fungi use protein kinases for mediating development and infection-related morphogenesis. Interestingly, it appears that $M$. grisea has a homolog of lipk. A BLAST search of the recently completed genomic sequence of M. grisea indicated that a hypothetical protein (contig 2.1229) has $69 \%$ amino acid identity to $C$. triofolii LIPK. It will be of interest to determine whether $M$. grisea protein has functional similarity to LIPK.

Thus, based on the available evidence, it appears that $C$. trifolii senses host surface chemistry to induce gene expression required for pathogenic development. We also have detected cutinolytic activity in this fungus (unpublished); thus, a plausible scenario is that $C$. trifolii spores land on the host surface, and endogenous cutinase hydrolyzes the cutin polymer into its monomeric long-chain fatty acids which, in turn, trigger induction of LIPK, which is necessary for appressoria development and subsequent host penetration and colonization. Our data also show a clear structural specificity for cutin monomers. When the midchain hydroxyl group of $8,16-$ dihyroxyhexadecanoic was removed, the induction of lipk transcription was prevented; 16-hydroxyhexadecanoic acid was unable to trigger LIPK expression (Fig. 5). This stringent structural requirement for lipk transcription is consistent with the conclusion that the observed lipk gene expression is a result of the ability of the fungal spore to sense the plant host surface, resulting in the induction of gene expression for pathogenic development. Thus, $C$. trifolii is able to use host plant components as signal molecules to trigger gene expression required for disease.

\section{MATERIALS AND METHODS}

\section{Strains and culture conditions.}

C. trifolii race 1 (ATCC 66954) was used throughout these studies. The fungus was stored as mycelia on dry filters at $-20^{\circ} \mathrm{C}$ and propagated in YPSS liquid medium $(0.4 \%$ yeast extract, $2 \%$ soluble starch, $0.1 \%$ potassium phosphate, $0.05 \%$ magnesium sulfate, pH 6.8) (Dickman et al. 1995). Mycelia were collected by filtration after 4 to 5 days' growth in liquid medium at room temperature with shaking $(125 \mathrm{rpm})$. To obtain germinated conidia and appressoria, washed conidia $\left(10^{6}\right.$ conidia $\left./ \mathrm{ml}\right)$ were suspended in water and poured into glass petri dishes $(5$ $\mathrm{ml} /$ petri dish) at ambient temperature. After $>80 \%$ of the conidia germinated ( 2 to $3 \mathrm{hr}$ ), the surface of the petri dish was
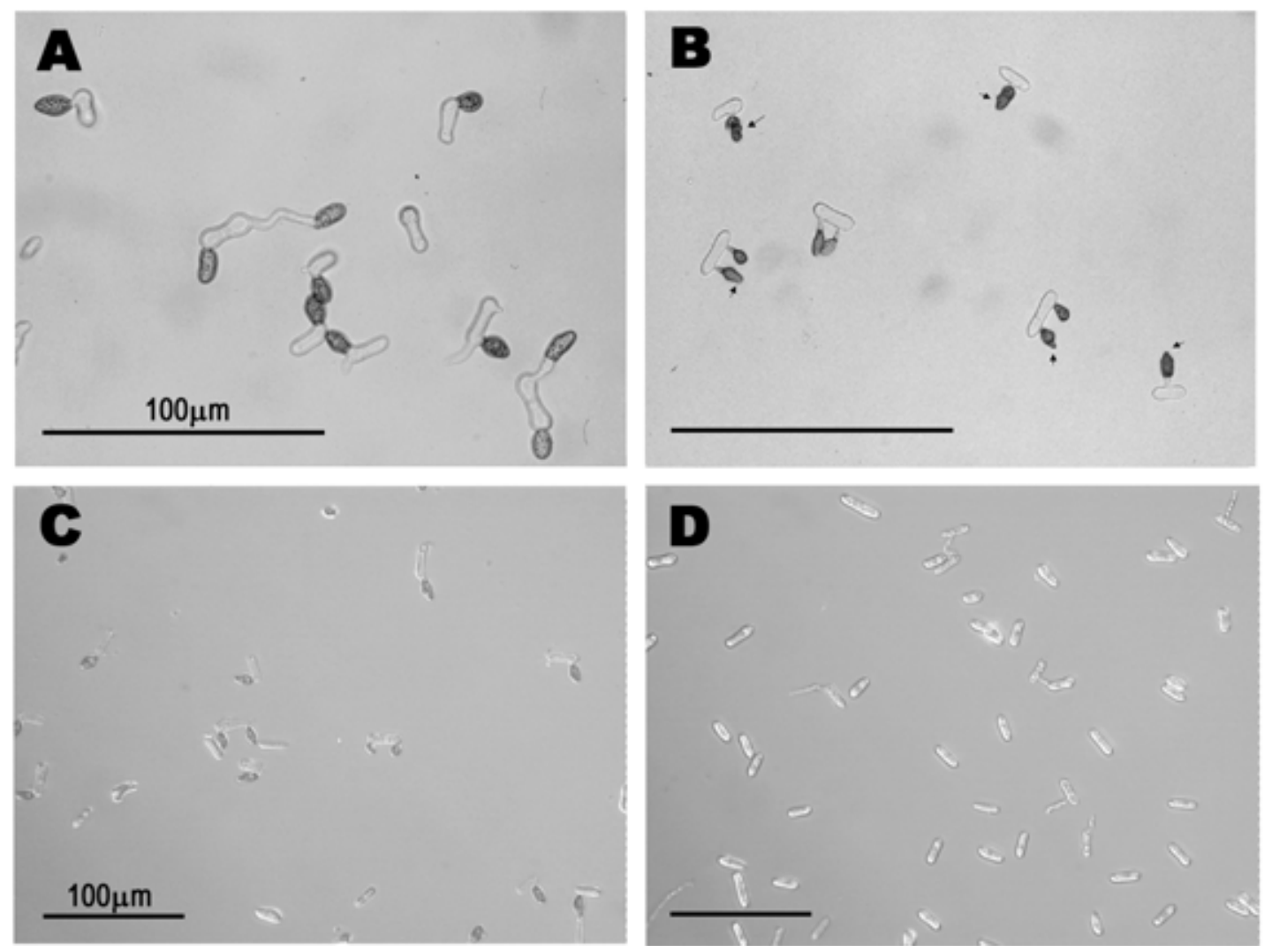

Fig. 6. Lipid-induced protein kinase (LIPK) overexpression results in abnormal appressorium development and lipk disruption mutants do not form appressoria. A, C, Colletotrichum trifolii wild type, A: $\times 400$, B: $\times 200$. B, LIPK overexpressing $C$. trifolii strain. Multiple aberrant appressoria were indicated by arrows. D, The lipk disruption mutant; $10^{4} \mathrm{spores} / \mathrm{ml}$ were inoculated onto an inductive surface (glass slide) for $7 \mathrm{hr}$. 
scrubbed with a rubber policeman to resuspend germinating conidia, and these germinating conidia were collected by centrifugation at $5,000 \mathrm{rpm}$ at $4^{\circ} \mathrm{C}$ for $10 \mathrm{~min}$. The pellet was immediately frozen in liquid nitrogen and stored at $-80^{\circ} \mathrm{C}$. Appressoria were collected by inducing germinated conidia to differentiate on a hard surface (Yang and Dickman 1997) and collected as described above. For lipid induction experiments, conidia were mixed with distilled water, nutrient media, cutin, or purified chemicals in Eppendorf tubes at $10^{5}$ or $10^{6}$ conidia/ml. Purified chemicals included 8, 16-dihydroxyhexadecanoic acid and 9, 12-octadecadienoic acid, gifts from R. Bostock (University of California-Davis), 9, 10, 16-trihydroxyhexadecanoic (aleuritic) acid (Fluka Chemical, Ronkonkoma, NY, U.S.A.), and 16-hydroxyhexadecanoic acid (Sigma, St. Louis). Media included $0.4 \%$ (wt/vol) yeast extract, $4.0 \%$ yeast extract, salt tryptone broth, or $0.5 \%$ apple cutin (Woloshuk and Kolattukudy 1986). Each sample $(100 \mu \mathrm{l})$ then was aliquoted onto glass slides (LabTek, Christchurch, New Zealand). E. coli cultures were grown on Luria-Bertani agar of $2 \times$ yeast extract tryptone media (Sambrook et al. 1989). Selective medium contained carbenicillin or ampicillin at $10 \mu \mathrm{g} / \mathrm{ml}$, tetracycline at 10 $\mu \mathrm{g} / \mathrm{ml}$, or kanamycin at $25 \mu \mathrm{g} / \mathrm{ml}$, as necessary.

\section{Isolation of LIPK.}

To obtain the LIPK gene, degenerate primers were designed based upon sequence alignment of two highly conserved regions of the protein kinase $\mathrm{C}$ catalytic domain. The forward primer was 32-fold degenerate corresponding to the sequence RDLKPE, (5'-AGRGACCTNAARCCSGAG-3'). The reverse

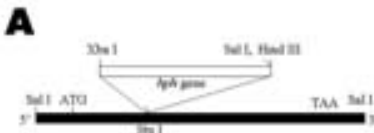

Full length lipk cDNA

B

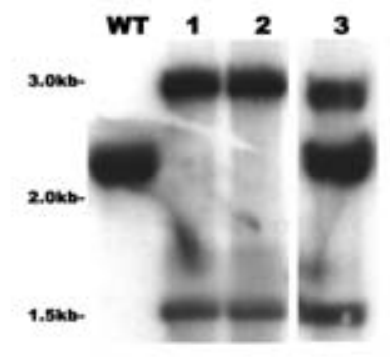

C

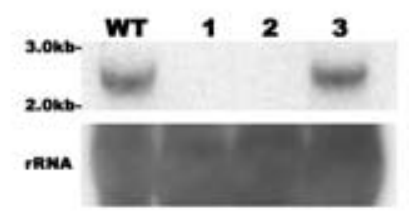

Fig. 7. Gene replacement vector and transformants. A, A plasmid map of lipid-induced protein kinase gene (lipk) and gene replacement vector. B, DNA analysis of lipk disruption mutant. $5 \mu \mathrm{m}$ of genomic DNA was digested with SalI, blotted, and hybridized with lipk cDNA. WT, $C$. trifolii wild type; lanes 1 and 2, two lipk disruption mutants; lane 3, an ectopic mutant (lane 4). C, RNA blot analysis of lipk and gene replacement strains. Total RNA $(15 \mu \mathrm{g})$ was isolated as described and hybridized with lipk cDNA. WT, wild type $C$. trifolii; lanes 1 and 2, lipk replacement mutants; lane 3 , lipk ectopic insertion mutant. primer was 64-fold degenerate corresponding to the sequence DWWSLG, (5'-NCCNAGSGACCACCARTC-3'). PCR reactions employed standard conditions containing $200 \mathrm{ng}$ of fungal genomic DNA as template, $50 \mu \mathrm{M}$ of each primer with a hot start at $95^{\circ} \mathrm{C}$ for $5 \mathrm{~min}$ followed by $94^{\circ} \mathrm{C}$ for $30 \mathrm{sec}, 55^{\circ} \mathrm{C}$ for $30 \mathrm{sec}$, and $72^{\circ} \mathrm{C}$ for $1 \mathrm{~min}$. PCR products were separated by a $2 \%$ agarose gel, and the predicted a band of approximately 200 bp was gel purified and cloned. This DNA was sequenced and subsequently radio labeled to use as a probe to screen a germinating spore cDNA library of $C$. trifolii.

\section{Nucleic acid manipulations.}

Colletotrichum genomic DNA was isolated as described (Panaccione et al. 1988), except that total DNA was purified in a single cesium chloride gradient. Total RNA from vegetative mycelia was purified according to published procedures (Cathala et al. 1983). RNA for Northern blots was purified with Trizol (Gibco BRL, Gaithersburg, MD, U.S.A.) according to the manufacture's instructions. Plasmids and phage DNA were isolated as described (Sambrook et al. 1989).

For construction of the cDNA library, mRNA from germinating spores of $C$. trifolii race 1 was isolated. PolyA RNA was isolated with Dynabeads (Dynal) according to the manufacturer's directions. cDNA was synthesized with random hexanucleotide, and adapters containing EcoRI, NotI, and SalI restriction sites were ligated to both cDNA ends. EcoRIdigested cDNA fragments were ligated into EcoRI-digested $\lambda$ gt11 arms and packaged in vitro as previously described. Plaque hybridizations employed random primer labeling (Feinberg and Vogelstein 1983) using the PCR-generated probe.

DNA was subcloned in E. coli strain DH5 $\alpha$ or XL-1 with plasmid vectors pBluescript $\mathrm{KS}^{+}$. Deletions were generated by restriction endonuclease digestion and Klenow end-repair, followed by ligation and transformation. DNA was sequenced using the dideoxy chain-termination method (Sanger et al. 1977) using three-lane sequencing as described by Nelson and associates (1992). Oligonucleotides were synthesized on an Applied Biosystems nucleic acid synthesizer (PCR-Mate). All enzymes were used according to manufacturers' specifications.

DNA samples $(0.75 \mu \mathrm{g} / \mathrm{lane})$ were electrophoresed on $0.8 \%$ agarose gels in $0.5 \times$ Tris-borate-EDTA buffer (Sambrook et al. 1989) and transferred to nylon membranes with $0.5 \mathrm{M}$ sodium hydroxide by the method of Southern as described by Sambrook and associates (1989). Probes were labeled with $\left[{ }^{32} \mathrm{P}\right]$-dCTP using the random priming method of Feinberg and Vogelstein (1983). Hybridization was carried out using a 25-ng probe in $10 \mathrm{ml}$ of hybridization $5 \times$ SSPE $(1 \times$ SSPE is $0.18 \mathrm{M}$ $\mathrm{NaCl}, 10 \mathrm{mM} \mathrm{NaPO}$, and $1 \mathrm{mM}$ EDTA $\{\mathrm{pH} 7.7]), 5 \times$ Denhardt's (Sambrook et al. 1989), 0.5\% sodium dodecyl sulfate (SDS), and $20 \mu \mathrm{g}$ of single-stranded salmon sperm $\mathrm{DNA} / \mathrm{ml}$ at $65^{\circ} \mathrm{C}$ for $20 \mathrm{hr}$. Filters were washed at high stringency, including two washed in $0.2 \times \mathrm{SSPE}, 0.1 \%$ SDS at $65^{\circ} \mathrm{C}$ for $20 \mathrm{~min}$ each. Filters were exposed to Kodak X-omat film at $-70^{\circ} \mathrm{C}$ using intensifying screens.

RNA was isolated at various developmental stages for Northern analysis. For Northern hybridization, aliquots $(10 \mu \mathrm{g})$ of RNA were mixed with $0.48 \mu \mathrm{g}$ of ethidium bromide, $1 \mu \mathrm{l}$ of formamide, and $1 \mu \mathrm{l}$ of $10 \times$ MOPS-buffered $0.2 \mathrm{M} 3-(\mathrm{N}-$ morpholino) propanesulfonic acid, $80 \mathrm{mM}$ sodium acetate $\mathrm{pH}$ 7, $10 \mathrm{mM}$ EDTA, and $3 \mathrm{M}$ formaldehyde in 10- $\mu$ l volumes. Samples were heated at $75^{\circ} \mathrm{C}$ for $5 \mathrm{~min}$ prior to adding $1.1 \mu \mathrm{l}$ of $10 \times$ loading dye $(0.25 \%$ bromophenol blue, $0.25 \%$ xylene cyanol, 25\% Ficoll, 10 mM EDTA) and loading on 1\% agarose gels in $1 \times$ MOPS buffer. Gels were run at $3 \mathrm{~V} / \mathrm{cm}$ for $3.5 \mathrm{hr}$ in $1 \times$ MOPS buffer. Gels were soaked twice in $2 \times$ SSPE for 15 min each. RNA was blotted onto MagnaGraph nylon filters 
(MSI) with 20× SSPE for $16 \mathrm{hr}$ and subsequently fixed by ultraviolet irradiation. Blots were hybridized with labeled fulllength lipk cDNA in $0.25 \mathrm{M}$ dibasic sodium phosphate, $\mathrm{pH} 7.4$, $7 \%$ SDS, 2\% blocking reagent (Boehringer Mannheim, Indianapolis, IN, U.S.A.), and 1 mM EDTA. A 1.4-kb BamHIEcoRI fragment encoding $17 \mathrm{~S}$ ribosomal DNA from $N$. crassa (Free et al. 1979) was labeled with digoxigenin-dUTP by random priming and served as an internal control to ensure equivalent loadings. RNA signals were normalized relative to $17 \mathrm{~S}$ ribosomal Neurospora crassa DNA signals by computer imaging and analysis using Collage software by Fotodyne. Hybridizations included a $25-\mathrm{ng}$ probe in a $10-\mathrm{ml}$ solution at $65^{\circ} \mathrm{C}$ for $20 \mathrm{hr}$. Filters were washed at high stringency, including two washes in $0.2 \times \mathrm{SSPE}, 0.1 \% \mathrm{SDS}$ at $65^{\circ} \mathrm{C}$ for 20 min each. Digoxigenin detection with the chemiluminescent substrate Lumi-Phos 530 was according to the manufacturer's (Boehringer Mannheim) instructions. Nucleotide and amino acid sequence analysis employed programs from the University of Wisconsin Genetics Group (Devereux et al. 1984). Amino acid sequence comparison and alignments were made with Bestfit, Pileup, and Boxsheet Programs (Morrison and Ellis 1997; Rechid et al. 1989). The GenBank accession number for lipk is AF046923.

\section{Western analysis, immunoprecipitation studies, and kinase assays.}

For Western studies, total fungal proteins were fractionated by a $10 \%$ SDS-polyacrylamide gel electrophoresis (PAGE) (Laemmli 1970) and transferred to nitrocellulose (Towbin et al. 1979). The filter was incubated in the blocking solution without Tween-20 with various PKC antibodies (Santa Cruz Biotechnology.) at a 1:1000 dilution at room temperature for 1 hr. After treating with washing buffer two times (20 mM Tris $\mathrm{HCl}, \mathrm{PH} 7.5,500 \mathrm{mM} \mathrm{NaCl}, 0.05 \%$ Tween-20), the filter was incubated with biotinylated anti-rabbit immunoglobulin $G$ (Amersham Life Science, ECL) for $1 \mathrm{hr}$ at room temperature and subsequently washed three times for $30 \mathrm{~min}$ in washing buffer. The filter was exposed to X-ray film for 5 to $10 \mathrm{~min}$.

Immunoprecipitation and autophosphorylation assays were performed essentially as described by (Osada et al. 1992). Briefly, total fungal proteins were isolated by sonication in buffer $(50 \mathrm{mM}$ Tris $\mathrm{HCl}, \mathrm{pH} 7.0,1 \mathrm{mM}$ dithiothreitol, $10 \mathrm{mM}$ $\mathrm{MnC}_{2}$ ). To assess autophosphorylation, $10 \mu \mathrm{Ci}$ of $\left[{ }^{32} \mathrm{P}\right]$-dATP was added to a final volume on $50 \mu \mathrm{l}$ containing $50 \mu \mathrm{g}$ of total proteins and incubated at room temperature for $10 \mathrm{~min}$. Following treatment with selected PKC antibodies, the immunoprecipitates were washed twice and dissolved in $15 \mu \mathrm{l}$ of $1 \times$ SDS sample buffer and subjected to SDS-PAGE. The gel was dried and exposed to X-ray film. Protein kinase $\mathrm{C}$ assays were performed using a commercially available kit (GibcoBRL) with myelin basic protein as a model substrate.

\section{Phylogenetic analysis.}

The amino acid sequence of LIPK was aligned to exemplar PKC, PKA, PKB, and general serine or threonine kinases (GenBank accession numbers D90242, M17074, U27191, M81709, X61036, U82936, X05998, U05811, X12560, X61037, D30041, L07032, J04848, J02626, D11091, M18330, D14338, and M13973). Sequences were aligned in Clustal X (Thompson et al. 1997) and edited manually in MacClade 4.0.2 (Maddison and Maddison 2001). Highly divergent regions (dubious homology statements) were removed prior to analysis, yielding 314 aligned positions. A maximum likelihood tree was constructed assuming a JTT model of substitution (Jones et al. 1992). Amino acid frequencies were estimated from the data set, as was the gamma distribution of rate heterogeneity (12 categories). A quartet puzzling tree search analyzed 100,000 puzzling steps and 3,876 quartets (PUZZLE 4.0.2) (Strimmer and von Haeseler 1996). A $\chi^{2}$ test revealed no departure from amino acid composition among the aligned sequences.

\section{Effects of kinase inhibitors on fungal development.}

Conidia were collected from liquid culture 1 to 2 days after sporulation. Conidia were concentrated by centrifugation $\left(5,000 \mathrm{rpm}\right.$ for $10 \mathrm{~min}$ at $\left.4^{\circ} \mathrm{C}\right)$. The pellet was washed twice in double-distilled $\mathrm{H}_{2} \mathrm{O}$ and resuspended to a concentration of $10^{6}$ conidia/ml. Germination tests were performed by placing 100 $\mu \mathrm{l}$ of the conidial suspension on glass slides and incubating in the dark. Percentage conidial germination was measured by counting under a light microscope. For each test, a minimum of 100 conidia were counted in three replicates.

For inhibitor assays, conidia were resuspended in YPSS media and placed onto glass slides. After germ tubes were observed under the microscope, medium was washed off and replaced with either water or water containing inhibitor. Appressoria were counted $2 \mathrm{hr}$ after this treatment and analyzed as described above. Samples on glass slides were set on wet sponges in closed plastic containers to maintain high humidity. Samples were incubated at room temperature without agitation prior to microscopic examination. Microscopic examination of a minimum of 100 conidia/sample required less than $3 \mathrm{~min} / \mathrm{sample}$ and was completed within $1.5 \mathrm{~min}$ of the designated time point. Conidia with emerging germ tubes were counted as germinated conidia. Conidia with bulbous germ tube ends (protoappressoria) eventually matured into fully melanized appressoria by $10 \mathrm{hr}$ and were counted as appressoria.

\section{Transformation-mediated gene replacement} and characterization of LIPK disruption mutants.

The 2.1-kb HindIII-XbaI fragment from pHA 1.3 (Powell and Kistler 1990) containing the hygromycin B phosphotransferase $(h p h)$ gene cassette was end-filled with Klenow, and subcloned into the blunt-ended StuI site in pBluescript-lapk. A 4.5-kb NotI fragment containing the disrupted gene was excised from the resulting construct, gel purified, and transformed into protoplasts of the wild-type $C$.

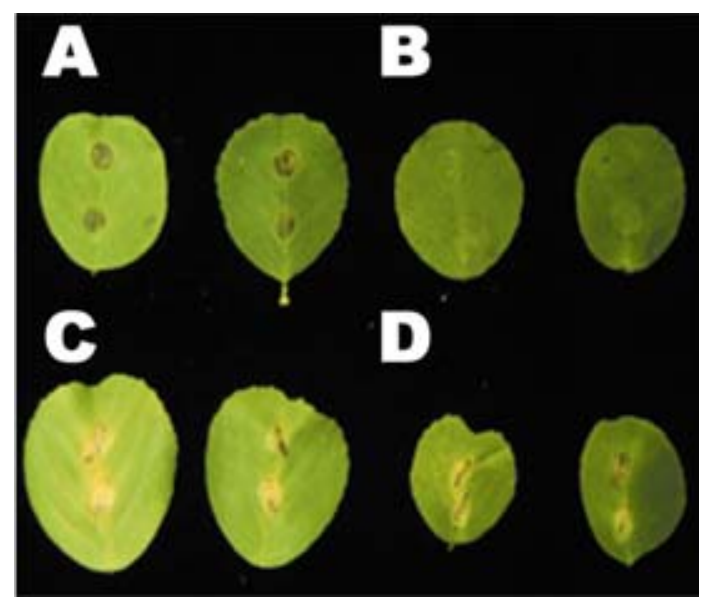

Fig. 8. Lipid-induced protein kinase gene (lipk) disruption mutants are nonpathogenic on intact detached alfalfa leaves. Conidia from wild-type and knockout strains were obtained following growth in yeast extract, peptone, soluble starch (YPSS) liquid media, washed, and diluted to $5 \times$ $10^{5} \mathrm{spores} / \mathrm{ml}$. After the addition of Tween $20(0.1 \%)$, droplets $(2 \mu \mathrm{l})$ were inoculated onto 1-month-old detached leaves. Inoculated leaves were incubated in $100 \%$ humidity at ambient temperature. The picture was taken 16 days post inoculation. A, Wild-type Colletotrichum trifolii on intact leaves; B, lipk disruption mutant on intact leaves; $\mathbf{C}$, wild type on wounded leaves; $\mathbf{D}$, disruption mutant on wounded leaves. 
trifolii. Transformation of $C$. trifolii was as described (Truesdell et al. 2000). Putative transformants growing on hygromycincontaining media at $150 \mu \mathrm{g} / \mathrm{ml}$ were selected after two rounds of single spore isolation. Identification of the lipk replacement mutants was accomplished by PCR analysis and confirmed by Southern hybridization.

The lipk disruption mutants were characterized and compared to the wild type with respect to growth rates, spore germination, appressorium formation, and pathogenicity on both detached leaves and intact susceptible alfalfa plants. Conidia (5 to 7 days old) grown on hygromycin-containing agar were harvested, washed twice with sterile water, and diluted to a concentration of $10^{5}$ conidia $/ \mathrm{ml}$. The conidial suspension was placed on the surface of a microscope slide, incubated at room temperature, and evaluated for germination and appressorium formation. For pathogenicity studies, conidia were harvested as described above and diluted in sterile $0.1 \%$ Tween 20 to a final concentration of $5 \times 10^{5}$ conidia $/ \mathrm{ml}$. Pathogenicity of lapk disruption mutants was determined with the alfalfa cultivar Saranac (Yang and Dickman 1999). Alfalfa leaves (1 month old) were detached and inoculated by placing $10 \mu \mathrm{l}$ of a spore suspension onto the surface leaf. Whole plants were inoculated by spraying a similar spore suspension until runoff. To maintain high humidity, detached leaves were incubated in sealed plates and whole plants were covered by plastic bags.

\section{ACKNOWLEDGMENTS}

This work was supported by the United States-Israel Binational Agriculture Research and Development Fund (BARD no. 2814-96).

\section{LITERATURE CITED}

Azzi, A., Boscoboinik, D., and Hensey, C. 1992. The protein kinase C family. Eur. J. Biochem. 208:547-557.

Bhairi, S. M., Buckley, E. H., Freve, P., and Staples, R. C. 1990. Protein synthesis and gene expression during appressorium formation in Glomerella magna. Exp. Mycol. 13:698-708.

Bhairi, S. M., Staples, R. C., Freve, P., and Yoder, O. C. 1989 Characterization of an infection structure-specific gene from the rust fungus, Uromyces appendiculatus . Gene 81:237-243.

Buhr, T. L., and Dickman, M. B. 1997. Gene expression analysis during conidial germtube and appressorium development in Colletotrichum trifolii. Appl. Environ. Microbiol. 63:2378-2383.

Cathala, G., Savouret, J. F., Mendez, B., West, B. L., Karin, M., Martial, J. A., and Baxter, J. D. 1983. A method for isolation of intact, translationally active ribonucleic acid. DNA 2:329-335.

de Jong, J. C., McCormack, B. J., Smirnoff, N., and Talbot, N. J. 1997. Glycerol generates tugor in rice blast. Nature 389:244-245.

Devereux, J., Haeberli, P., and Smithies, O. 1984. A comprehensive set of sequence analysis programs for the VAX. Nucleic Acids Res. 12:387395.

Dickman, M. B. 2000a. Colletotrichum. In: Fungal Pathology. Academic Publisher, London.

Dickman, M. B. 2000b. Signal exchange during Colletotrichum trifoliialfalfa interactions. In: Colletotrichum: Host specificity, Pathology and host-pathogen interaction., American Phytopathological Society Press, St. Paul, MN.

Dickman, M. B., Bhur, T. L., Warwar, V., Truesdell, G. M., and Huang, C. 1995. Molecular signals during the early stages of alfalfa anthracnose. Can. J. Bot. 73:1169-1177.

Dickman, M. B., Podila, G. K., and Kolattukudy, P. E. 1989. Insertion of cutinase gene into a wound pathogen enables it to infect intact host. Nature 342:446-448.

Dickman, M. B., and Yarden, O. 1999. Serine/threonine protein kinases and phosphatases in filamentous fungi. Fungal Genet. Biol. 26:99-117.

Dixon, K. P., Xu, J. R., Smirnoff, N., and Talbot, N. J. 1999. Independent signaling pathways regulate cellular turgor during hyperosmotic stress and appressorium-mediated plant infection by Magnaporthe grisea. Plant Cell 11:2045-2058.

Durrenberger, F., Laidlaw, R. D., and Kronstad, J. W. 2001. The hgl1 gene is required for dimorphism and teliospore formation in the fungal pathogen Ustilago maydis. Mol. Microbiol. 41:337-348.
Eisen, J. A. 1998. Phylogenomics: Improving functional predictions for uncharacterized genes by evolutionary analysis. Genome Res. 8:163167.

Feinberg, A. P., and Vogelstein, B. 1983. A technique for radiolabeling DNA restriction endonuclease fragments to high specific activity. Anal. Biochem. 132:6-13.

Free, S. J., Rice, P. W., and Metzenberg, R. L. 1979. Arrangement of the genes coding for ribosomal ribonucleic acids in Neurospora crassa. J. Bacteriol. 137:1219-1226.

Garrill, A., Lew, R. R., and Heath, I. B. 1992. Measuring mechanosensitive channels in Uromyces. Science 256:1335-1336.

Gold, S. E., Brogdon, S. M., Mayorga, M. E., and Kronstad, J. W. 1997. The Ustilago maydis regulatory subunit of a cAMP-dependent protein kinase is required for gall formation in maize. Plant Cell 9:1585-1594.

Goodman, M., Weiss, M. L., and Czelusniak, J. 1982. Molecular evolution above the species level: Branching patterns, rates, and mechanisms. Syst. Zoology 31:376:399.

Grant, S., and Jarvis, W. D. 1996. Modulation of drug-induced apoptosis by interruption of the protein kinase $\mathrm{C}$ signal transduction pathway: a new therapeutic strategy. Clin. Cancer Res. 2:1915-1920.

Gschwendt, M., Muller, H. J., Kielbassa, K., Zang, R., Kittstein, W., Rincke, G., and Marks, F. 1994. Rottlerin, a novel protein kinase inhibitor. Biochem. Biophys. Res. Commun. 199:93-98.

Hanks, S. K., and Quinn, A. M. 1991. Protein kinase catalytic domain sequence database: identification of conserved features of primary structure and classification of family members. Methods Enzymol 200:38-62.

Hoch, H. C., Staples, R. C., Whitehead, B., Comeau, J., and Wolfe, E. D. 1987. Signalling for growth orientation and cell differentiation by surface topography in Uromyces. Science 235:1659-1662.

House, C., and Kemp, B. E. 1987. Protein kinase C contains a pseudosubstrate prototope in its regulatory domain. Science 238:17261728.

Howard, R. J., Ferrari, M. A., Roach, D. H., and Money, N. P. 1991. Penetration of hard substrates by a fungus employing enormous turgor pressures. Proc. Natl. Acad. Sci. USA 88:11281-11284.

Jarvis, W. D., Fornari, F. A., Traylor, R. S., Martin, H. A., Kramer, L. B., Erukulla, R. K., Bittman, R., and Grant, S. 1996. Induction of apoptosis and potentiation of ceramide-mediated cytotoxicity by sphingoid bases in human myeloid leukemia cells. J. Biol. Chem. 271:8275-8284.

Jones, D. T., Taylor, W. R., and Thornton, J. M. 1992. The rapid generation of mutation data matrices from protein sequences. Comput. Appl. Biosci. 8:275-282.

Kim, Y. K., Hoch, H. C., and Staples, R. C. 1991. Cytoskeletal organization in Uromyces urediospores germling apieces during appressorium formation. Protoplasma 165:37-50.

Kolattukudy, P. E. 1985. Enzymatic penetration of the plant cuticle by fungal pathogens. Annu. Rev. Phytopathol. 23:223-250.

Kubo, K., Ohno, S., Matsumoto, S., Yahara, I., and Suzuki, K. 1989. A novel yeast gene coding for a putative protein kinase. Gene 76:177180.

Laemmli, U. K. 1970. Cleavage of structural proteins during the assembly of the head of bacteriophage T4. Nature 227:680-685.

Maddison, W. P., and Maddison, D. R. 2001. MacClade, version 4.0.2. Sinauer, Sunderland, MA, U.S.A.

Martiny-Baron, G., Kazanietz, M. G., Mischak, H., Blumberg, P. M., Kochs, G., Hug, H., Marme, D., and Schachtele, C. 1993. Selective inhibition of protein kinase $\mathrm{C}$ isozymes by the indolocarbazole Go 6976. J. Biol. Chem. 268:9194-9197.

Maurer, R. A. 1988. Isolation of a yeast protein kinase gene by screening with a mammalian protein kinase cDNA. DNA 7:469-474.

Morawetz, R., Lendenfeld, T., Mischak, H., Muhlbauer, M., Gruber, F., Goodnight, J., de Graaff, L., Visser, J., Mushinski, J., and CP, K. 1996. Cloning and characterization of genes ( $p k c 1$ and $p k c A$ ) encoding protein kinase $\mathrm{C}$ homologues from Trichoderma reesei and Aspergillus niger. Mol. Gen. Genet. 250:17-28.

Morawetz, R., Mischak, H., Goodnight, J., Lendenfeld, T., Mushinsky, J. F., and Kubicek, C. P. 1994. A protein kinase-encoding gene, pkt1, from Trichoderma reesei, homologous to the yeast $Y P K 1$ and $Y P K 2$ (YKR2) genes. Gene 146:309-310.

Morrison, D. A., and Ellis, J. T. 1997. Effects of nucleotide sequence alignment on phylogeny estimation: a case study of $18 \mathrm{~S}$ rDNAs of apicomplexa. Mol. Biol. Evol. 14:428-441.

Mukai, H., Toshimori, M., Shibata, H., Kitagawa, M., Shimakawa, M., Miyahara, M., Sunakawa, H., and Ono, Y. 1996. PKN associates and phosphorylates the head-rod domain of neurofilament protein. J. Biol. Chem. 271:9816-9822.

Nelson, M., Van Etten, J. L., and Grabherr, R. 1992. DNA sequencing of four bases using three lanes. Nucleic Acids Res. 20:1345-1348. 
Nishizuka, Y. 1988. The molecular heterogeneity of protein kinase $\mathrm{C}$ and its implications for cellular regulation. Nature 334:661-665.

Oliver, S., van der Aart, Q., Agostoni-Carbone, M., Aigle, M., Alberghina, L., Alexandraki, D., Antoine, G., Anwar, R., Ballesta, J., and Benit P. E. A. 1992. The complete DNA sequence of yeast chromosome III. Nature 357:38-46.

Osada, S., Mizuno, K., Saido, T. C., Suzuki, K., Kuroki, T., and Ohno, S. 1992. A new member of the protein kinase $\mathrm{C}$ family, nPKC theta, predominantly expressed in skeletal muscle. Mol. Cell. Biol. 12:39303938.

Panaccione, D. G., McKiernan, M., and Hanau, R. M. 1988 Colletotrichum graminicola transformed with homologous and heterologous benomyl-resistant genes retains expected pathogenicity to corn. Mol Plant-Microbe Interact. 1:113-120.

Powell, W. A., and Kistler, H. C. 1990. In vivo rearrangement of foreign DNA by Fusarium oxysporum produces linear self-replicating plasmids. J. Bacteriol. 172:3136-3171.

Punt, P. J., Dingemanse, M. A., Kuyvenhoven, A., Soede, R. D., Pouwels, P. H., and van den Hondel, C. A. 1990. Functional elements in the promoter region of the Aspergillus nidulans gpdA gene encoding glyceraldehyde-3-phosphate dehydrogenase. Gene 93:101-109.

Rahmsdorf, H. J., and Herrlich, P. 1990. Regulation of gene expression by tumor promoters. Pharmacol. Ther. 48:157-188.

Rechid, R., Vingron, M., and Argos, P. 1989. A new interactive protein sequence alignment program and comparison of its results with widely used algorithms. Comput. Appl. Biosci. 5:107-113.

Sambrook, J., Fritsch, E. F., and Maniatis, T. 1989. Molecular Cloning: A Laboratory Manual., 2nd ed. Cold Spring Harbor Laboratory Press, Cold Spring Harbor, NY.

Sanger, F., Nicklen, S., and Coulson, A. R. 1977. DNA sequencing with chain-terminating inhibitors. Proc. Natl. Acad. Sci. USA 74:54635467.

Stanhope, M. J., Lupas, A., Italiz, M. J., Koretke, K. K., Volker, C., and Brown, J. R. 2001. Phylogenetic analyses do not support horizontal gene transfers from bacteria to vertebrates. Nature 411:940-944.

Strimmer, K., and von Haeseler, A. 1996. Quartet puzzling: a quartet maximum-likelihood method for reconstructing tree topologies. Mol. Biol. Evol. 13:964-969.

Tamaoki, T., Nomoto, H., Takahashi, I., Kato, Y., Morimoto, M., and Tomita, P. 1986. Staurosporin, a potent inhibitor of phospholipid/ $\mathrm{Ca}^{++}$ dependent protein kinase. Biochem. Biophys. Res. Commun. 135:397402

Thines, E., Weber, R. W., and Talbot, N. J. 2000. MAP kinase and protein kinase A-dependent mobilization of triacylglycerol and glycogen during appressorium turgor generation by Magnaporthe grisea. Plant Cell 12:1703-1718.

Thompson, J. D., Gibson, T. J., Plewniak, F., Jeanmougin, F., and Higgins, D. G. 1997. The CLUSTAL X windows interface: flexible strategies for multiple sequence alignment aided by quality analysis tools. Nucleic Acids Res. 25:4876-4882.

Towbin, H., Staehelin, T., and Gordon, J. 1979. Electrophoretic transfer of proteins from polyacrylamide gels to nitrocellulose sheets: procedure and some applications. Proc. Natl. Acad. Sci. USA 76:4350 4354.

Truesdell, G. M., Yang, Z., and Dickman, M. B. 2000. A G alpha sub-units form the phytopathogenic fungus Colletotrichum trifolii is required for conidial germination. Physiol. Mol. Plant Pathol. 56:131-140.

Tuker, S. L., and Talbot, N. J. 2001. Surface attachment and prepenetration stage development by plant pathogenic fungi. Annu. Rev. Phytopathol. 39:385-417.

van Kan, J. A., van't Klooster, J. W., Wagemakers, C. A., Dees, D. C., and van der Vlugt-Bergmans, C. J. 1997. Cutinase A of Botrytis cinerea is expressed, but not essential, during penetration of gerbera and tomato. Mol. Plant-Microbe Interact. 10:30-38.

Warwar, V., and Dickman, M. 1996. Effect of calcium and calmodulin on spore germination and appressorium development in Colletotrichum trifolii. Appl. Environ. Microbiol. 62:74-79.

Warwar, V., Oved, S., and Dickman, M. B. 2000. Antisense expression of the calmodulin gene from Colletotrichum trifolii impairs prepenetration development(1). FEMS Microbiol. Lett. 191:213-219.

Woloshuk, C. P., and Kolattukudy, P. 1986. Mechanism by which contact with plant cuticle triggers cutinase gene expression in the spores of Fusarium solani f. sp. pisi. Proc. Natl. Acad. Sci. USA 83:1704-1708.

Xu, J. R., and Hamer, J. E. 1996. MAP kinase and cAMP signaling regulate infection structure formation and pathogenic growth in the rice blast fungus Magnaporthe grisea. Genes Dev. 10:2696-2706.

$\mathrm{Xu}$, J. R., Staiger, C. J., and Hamer, J. E. 1998. Inactivation of the mitogen-activated protein kinase Mps1 from the rice blast fungus prevents penetration of host cells but allows activation of plant defense responses. Proc. Natl. Acad. Sci. USA 95:12713-12718.

Xu, J. R., Urban, M., Sweigard, J. A., and Hamer, J. E. 1997. The CPKA gene of Magnaporthe grisea is essential for appressorial penetration. Mol. Plant-Microbe Interact. 10:187-194.

Xuei, X., Bhairi, S., Staples, R. C., and Yoder, O. C. 1992. Characterization of INF56, a gene expressed during infection structure development of Uromyces appendiculatus. Gene 110:49-55.

Yang, Z., and Dickman, M. B. 1997. Regulation of cAMP and cAMP dependent protein kinase during conidial germination and appressorium formation in Colletotrichum trifolii. Physiol. Mol. Plant Pathol. 50:117-127.

Yang, Z., and Dickman, M. B. 1999. Colletotrichum trifolii mutants disrupted in the catalytic subunit of cAMP-dependent protein kinase are nonpathogenic. Mol. Plant-Microbe Interact. 12:430-439.

Zhang, Z., Priddey, G., and Gurr, S. J. 2001. The barley powdery mildew protein kinase $\mathrm{C}$ gene, $p k c 1$ and pkc-like gene, are differentially expressed during morphogenesis. Mol. Plant Pathol. 2:327-337. 